\title{
Usefulness of pyrolysis coupled to gas chromatography/mass spectrometry for evaluating the reproducibility of commercial samples of Cymbopogon citratus Stapf., Poaceae.
}

\author{
Eduardo J. Oliveira, "Enrique D. A. Alvarez, Naiana G. P. B. Lima, Rui O. Macedo
}

Programa de Pós-graduação em Produtos Naturais e Sintéticos Bioativos, Laboratório de Tecnologia Farmacêutica, Universidade Federal da Paraíba, Campus I, Caixa Postal 5009, 58051-970 João Pessoa-PB, Brazil.

\begin{abstract}
RESUMO:"Utilidade da técnica de pirólise acoplada a cromatografia gasosa/espectrometria de massas na avaliação da uniformidade de conteúdo de amostras comerciais de $C y m b o p o g o n$ citratus Stapf". A utilidade da técnica de pirólise acoplada à cromatografia à gás/espectrometria de massas (Py-GC/MS) na avaliação da identidade e reprodutibilidade de diferentes marcas e lotes de amostras comerciais de Cymbopogon citratus Stapf. (comercializado como chá) foi investigada. Amostras do material vegetal foram extraídas com hexano e o extrato foi diretamente pirolisado a $450{ }^{\circ} \mathrm{C}$ utilizando um pirolisador de microforno vertical, interfaciado diretamente com um cromatógrafo à gás/espectrômetro de massas, operado utilizando ionização por impacto eletrônico a $70 \mathrm{eV}$. As áreas relatives dos picos de interesse identificados nos pirogramas foram utilizadas para análise estatística multivariada, com análise de componentes principais e análise hierárquica de agrupamentos. A análise de components principais dos dados de pirólise foi capaz de representar $84.7 \%$ da variabilidade total nos dois primeiros componentes calculados e levou a correta classificação das amostras testadas. O método foi capaz de revelar diferenças importantes entre amostras, quando diferentes lotes da mesma marca foram comparados.
\end{abstract}

Unitermos: Pirólise, Cymbopogon citratus, análise multivariada, análise de componentes principais, análise de agrupamentos.

\begin{abstract}
The usefulness of pyrolysis coupled to gas chromatography/mass spectrometry (Py-GC/MS) to evaluate the identity and reproducibility of different brands and batches of commercially available samples of Cymbopogon citratus Stapf (sold as tea) was investigated. Samples of the vegetable material were extracted using hexane and the extract was pyrolysed at $450{ }^{\circ} \mathrm{C}$ using a vertical microfurnace pyrolyser interfaced directly with a gas chromatograph/mass spectrometer operated using electron impact ionization at $70 \mathrm{eV}$. The relative peak areas of the different compounds identified on the pyrograms were used for multivariate data analysis using principal component analysis (PCA) and hierarchical cluster analysis (HCA) techniques. Principal component analysis of pyrolysis data from samples of different brands was able to represent $84.7 \%$ of the total variability within the first two principal components, and led to the correct classification of the samples tested. The method was also able to reveal important differences between samples when different batches of the same brand were compared.
\end{abstract}

Keywords: Pyrolysis; Cymbopogon citratus; multivariate analysis; principal component; cluster analysis.

\section{INTRODUCTION}

The use of herbal medicines has been increasing in recent years (Calixto, 2000). In spite of the rich Brazilian flora, which represents more than $20 \%$ of the plant species known in the world (Petrovick et al., 1999) and the extensive use of herbal drugs in Brazil, more needs to be done to improve the quality of herbal drugs used in the country. In Brazil, the registration of herbal drugs is regulated by the national sanitary agency (Anvisa, 2004), through a specific legislation, which establishes criteria for ensuring that both traditional and innovative herbal drugs meet the criteria of safety and efficacy. To fulfill these needs, the difficulties associated with the chemical analysis of these complex samples in order to ensure batch-to-batch reproducibility is an important step to overcome.

Pyrolysis coupled to gas chromatography (PyGC) and pyrolysis coupled to gas chromatography interfaced with mass spectrometry (Py-GC/MS) are techniques used to allow the analysis of complex 
materials by gas chromatography by breaking them into more volatile fragments (White, 1991). The coupling of pyrolysis and capillary gas chromatography is beneficial to both techniques. Capillary gas chromatography is benefited since it has its application range extended to the analysis of complex and often non-volatile constituents in matrices such as biological samples, polymers, coal and plant materials. Pyrolysis on the other hand is benefited by the high resolving power of capillary columns, which are able separate the complex mixture obtained by pyrolysis of such materials (Wampler, 1999). Analytical pyrolysis is often considered poorly reproducible, and quantitative applications are not very common. Between the factors contributing to the poor reproducibility of the technique are sample inhomogeneity, slow transfer of the pyrolysate to the chromatographic column and catalytic events in the pyrolyser which may alter the chemical nature of the sample (Wampler \& Levy, 1987). Since Py-GC/MS of complex matrices such as vegetable material, polymers and biological samples result in a complex mixture of volatile fragments of the original sample, the resulting pyrogram can be used very effectively as a fingerprint of that particular sample. The analysis of the fingerprint pattern of these samples is often accomplished by use of multivariate statistical techniques.

Multivariate data analysis techniques are important in those instances where data containing multiple variables are measured over several samples, in order to reveal relationships that are not evident only from visual inspection of the data (Christy et al., 1999). These techniques are often used to reveal patterns within samples and relationships between variables. Two of the most used multivariate techniques are principal component analysis and hierarchical cluster analysis. A detailed description of recent applications of principal component analysis (PCA) and other multivariate statistical analysis techniques can be found elsewhere (Lavine, 1998).

Principal component analysis has been particularly useful in the analysis of pyrolysis data obtained from complex plant-derived materials. Thus, Wang et al (Wang et al., 2001) were able to discriminate among carnauba waxes collected from leaves at two different growing stages by reactive Py-GC with tetramethylammonium hydroxide (TMAH). Mitsui et al (Mitsui et al., 1995) studied the determination of the total amount of morphine alkaloids in opium by-gas chromatography using principal component analysis. Yokoi (Yokoi et al., 2001) used discriminative analysis of pyrolysis data to classify Eucalyptus camaldulensis samples grown from seeds of various origin based on lignin components measured by pyrolysis-gas chromatography.

The aim of the present study was to investigate the suitability of pyrolysis-gas chromatography/mass spectrometry (Py-GC/MS) with multivariate data analysis for the evaluation of batch-to-batch reproducibility of commercial samples of Cymbopogon citratus sold as tea, a herb widely used in Brazil also as a sedative, analgesic and antithermic (Diniz et al., 1997). This method may circumvent some of the problems associated to traditional methods used for the analysis of herbal drugs, since it is sensitive to variations in the pyrolysis pattern as a whole and not in the content of a single marker substance.

\section{EXPERIMENTAL}

\section{Samples and sample processing}

Cymbopogon citratus samples in the form of tea bags were obtained from the local commerce. Two brands of comercially available $C$. citratus tea bags were used and coded as: Ma (batches 154A and 154B) and FI (batches 3 and 7). An authentic sample of C. citratus from the medicinal garden of the Laboratorio de Tecnologia Farmaceutica (Joao Pessoa, PB) was also used for comparison purposes. The plant material was identified by Prof. Maria de Fatima Agra and a voucher specimen deposited in the JPB herbarium under the number 6739. The samples were processed in a rotary blade mill, (Tecnal TE-631, Brazil) and the powder obtained was sieved in a stainless steel sieve (200 Mesh). The plant material $(0,5$ g) was extracted using sonication (Branson 1510) with 10 $\mathrm{mL}$ of $n$-hexane (from Merck Darmstat, Germany) and 1 $\mu \mathrm{L}$ of the extract was analysed using a furnace pyrolyser (Shimadzu, Pyr-4A) set at $450^{\circ} \mathrm{C}$.

\section{Instrumentation}

The pyrolyser (Shimadzu, Pyr-4A) was directly interfaced with a gas chromatohraph/mass spectrometer (Shimadzu, GCMS-QP5050A). The column used was a dimethylpolysiloxane capillary column $(30 \mathrm{~m} \times 0.25 \mathrm{~mm}$ I.D., $0.25 \mu \mathrm{m}$ film thickness). The gas chromatograph was interfaced with the mass spectrometer, which was configured to scan a mass range from $m / z 35$ to 400 u.m.a. Helium was used as carrier gas at a flow rate of $14.28 \mathrm{~mL} /$ min to the pyrolyser and a 12:1 split ratio was used to reduce the flow to the column to $1.1 \mathrm{~mL} / \mathrm{min}$. The interface temperature was set at $300{ }^{\circ} \mathrm{C}$. Ionization was effected by electron impact (EI) at $70 \mathrm{eV}$. The chromatographic run was performed using a temperature ramp, starting at 90 ${ }^{\circ} \mathrm{C}$ and holding for $2 \mathrm{~min}$, followed by a $9{ }^{\circ} \mathrm{C} / \mathrm{min}$. ramp up to $270{ }^{\circ} \mathrm{C}$, and held for $20 \mathrm{~min}$. One microliter of the n-hexane extract was introduced in the pyrolyser through a platinum sample holder. The pyrolysis temperature was set at $450^{\circ} \mathrm{C}$. Each sample was analysed ten times.

\section{Data handling}

Principal component analysis (PCA) and hierarchical cluster analysis (HCA) were implemented using the software Statistica 6.0 (Statsoft Inc.). The peaks selected in each pyrogram were integrated and their relative 
areas were calculated by normalizing each peak relative to the total peak area. This data processing scheme was used for both PCA and HCA calculations. HCA was done using the single linkage method with computed Euclidian distances. The dendrogram was obtained by clustering the cases (samples).

\section{RESULTS}

Two different batches of each brand were analysed. The pyrolysis temperature was chosen based on preliminary experiments (data not shown) in which temperatures ranging from $350-650{ }^{\circ} \mathrm{C}$ were tested. The number of constituents detected in the pyrogram increased with the pyrolysis temperature up to $450{ }^{\circ} \mathrm{C}$, after which no significant increase in the number of constituents detected was observed. With higher pyrolysis temperatures, contamination of the pyrolyser's quartz liner was frequent, requiring a lenghty cleaning procedure. A visual analysis of the pyrograms shown in Figure 1 reveal that FI samples had a higher relative abundance of peaks with retention times situated between 25 and 35 min compared with samples from the Ma brand. Between the FI samples, those from batch 3 showed a higher relative abundance of the constituents with retention times between 12 and $18 \mathrm{~min}$ in relation to samples from batch 7 . Ten samples from each batch were analyzed and the relative peak areas of the constituents were then used for principal component analysis and cluster analysis.
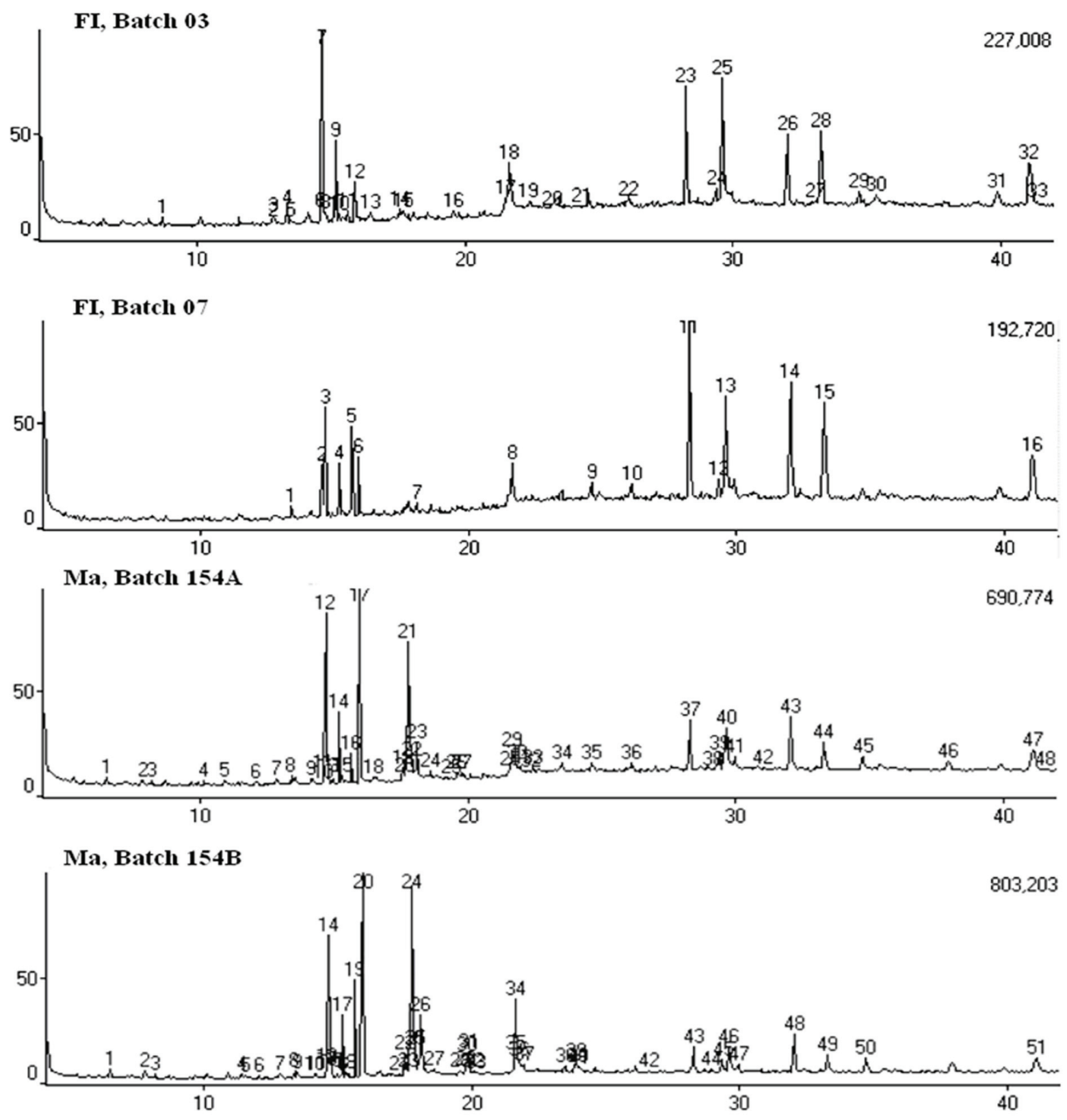

Figure 1. Representative pyrograms $\left(450^{\circ} \mathrm{C}\right)$ of commercial samples of Cymbopogon citratus of FI and Ma brands. 
Figure 2 shows a comparison between the pyrolysis patterns of a commercial sample of $C$. citratus and an authentic sample (botanically identified). As expected, the samples share a very similar pyrolysis pattern, although the relative abundances of individual peaks can differ significantly between samples. Table 1 lists retention data for the constituents in the pyrograms of Figure 2, and also a tentative peak assignment based on mass spectral data. The major constituents of the samples are high molecular weight alcohols and fatty acids.

Table 1. Tentative peak identification and comparison between a commercial and an authentic sample of $C$. citratus pyrolised both using the same conditions (see Figure 2).

\begin{tabular}{|c|c|c|c|}
\hline \multirow{2}{*}{$\begin{array}{l}\text { Peak number } \\
\text { (see Figure 2) }\end{array}$} & \multicolumn{2}{|c|}{ Retention time (min.) } & \multirow{2}{*}{ Peak assignment ${ }^{\mathrm{a}}$} \\
\hline & Commercial sample & Authentic sample & \\
\hline 1 & 20.0 & 19.9 & phytol \\
\hline 2 & 20.6 & 20.6 & neophytadiene \\
\hline 3 & 21.7 & 21.7 & palmitic acid \\
\hline 4 & 23.9 & 23.6 & $\mathrm{NI}^{\mathrm{b}}$ \\
\hline 5 & 24.0 & 24.0 & $\mathrm{NI}^{\mathrm{b}}$ \\
\hline 6 & 24.4 & 24.4 & estearic acid \\
\hline 7 & 32.4 & 32.3 & $\mathrm{NIb}$ \\
\hline 8 & 36.0 & 35.9 & tridecanal \\
\hline 9 & 37.3 & 37.2 & 1-eicosanol \\
\hline 10 & 39.6 & 39.4 & kaurene \\
\hline 11 & 41.0 & 40.8 & tetradecanal \\
\hline 12 & 47.5 & 47.2 & $\mathrm{NI}^{\mathrm{b}}$ \\
\hline 13 & 48.9 & 48.6 & hexadecanal \\
\hline
\end{tabular}

${ }^{a}$ tentative assignments based on mass spectral data ${ }^{b}$ not identified

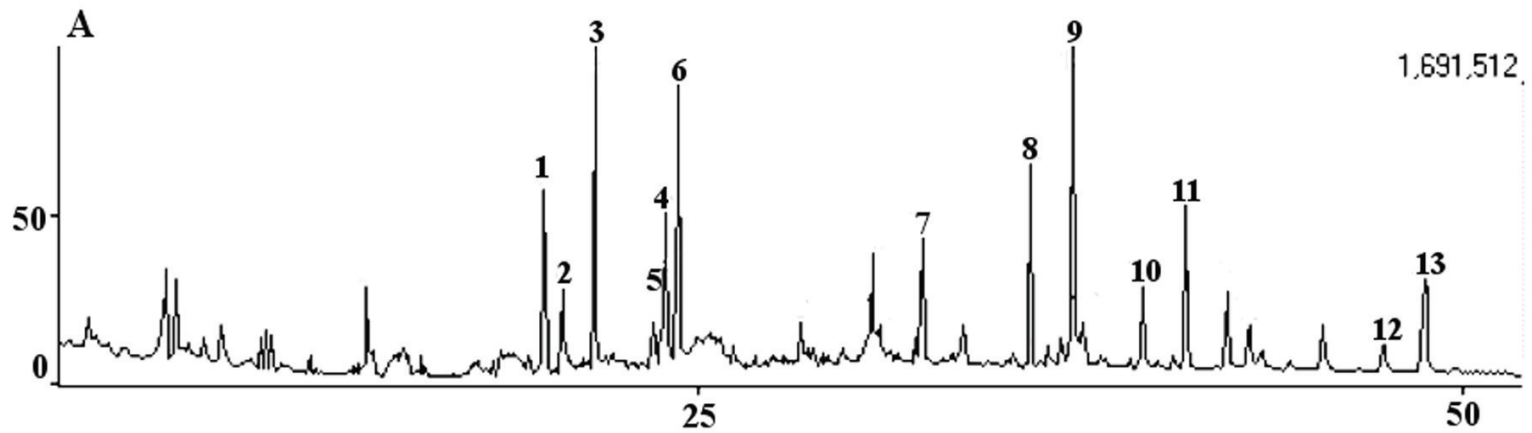

B

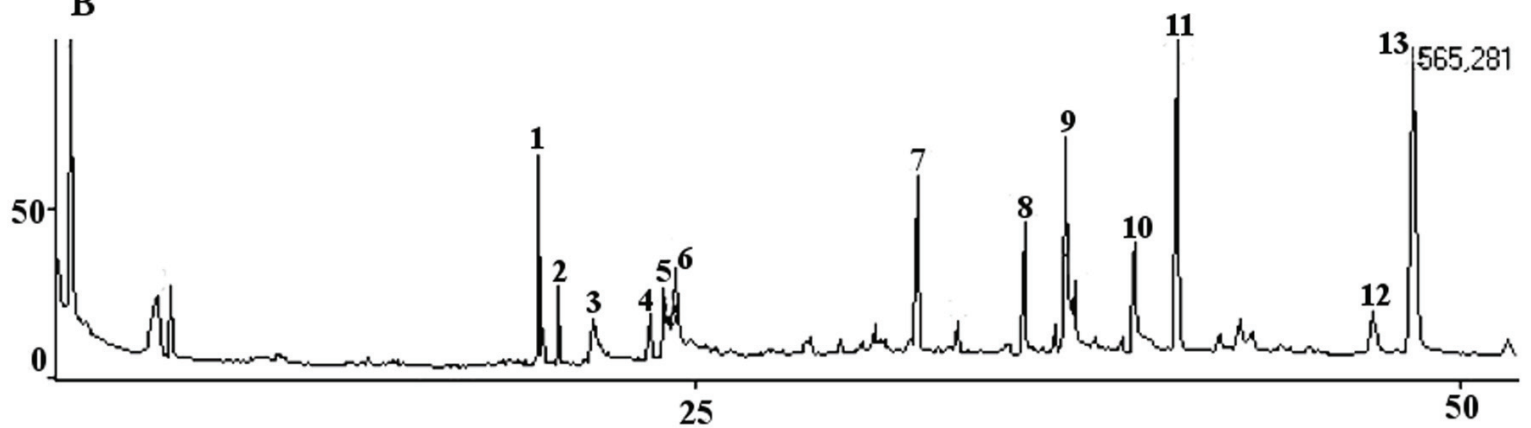

Figure 2. Comparision between the pyrolisis pattern of a hexane extract from a commercial sample (A) and an authentic sample of C. citratus (B) pyrolised both at $450^{\circ} \mathrm{C}$. For tentative peak assignments see Table 1 . 
The plot shown in Figure 3 is the factor scores for samples from the brands Ma and FI in the first two principal components. It can be seen that the first two principal components accounted together for $84.7 \%$ of the total variance. This allowed a good spacial separation of the samples, which clustered into 3 different groups, corresponding to the 2 FI batches (which clustered separately) and the $2 \mathrm{Ma}$ batches (which clustered together).

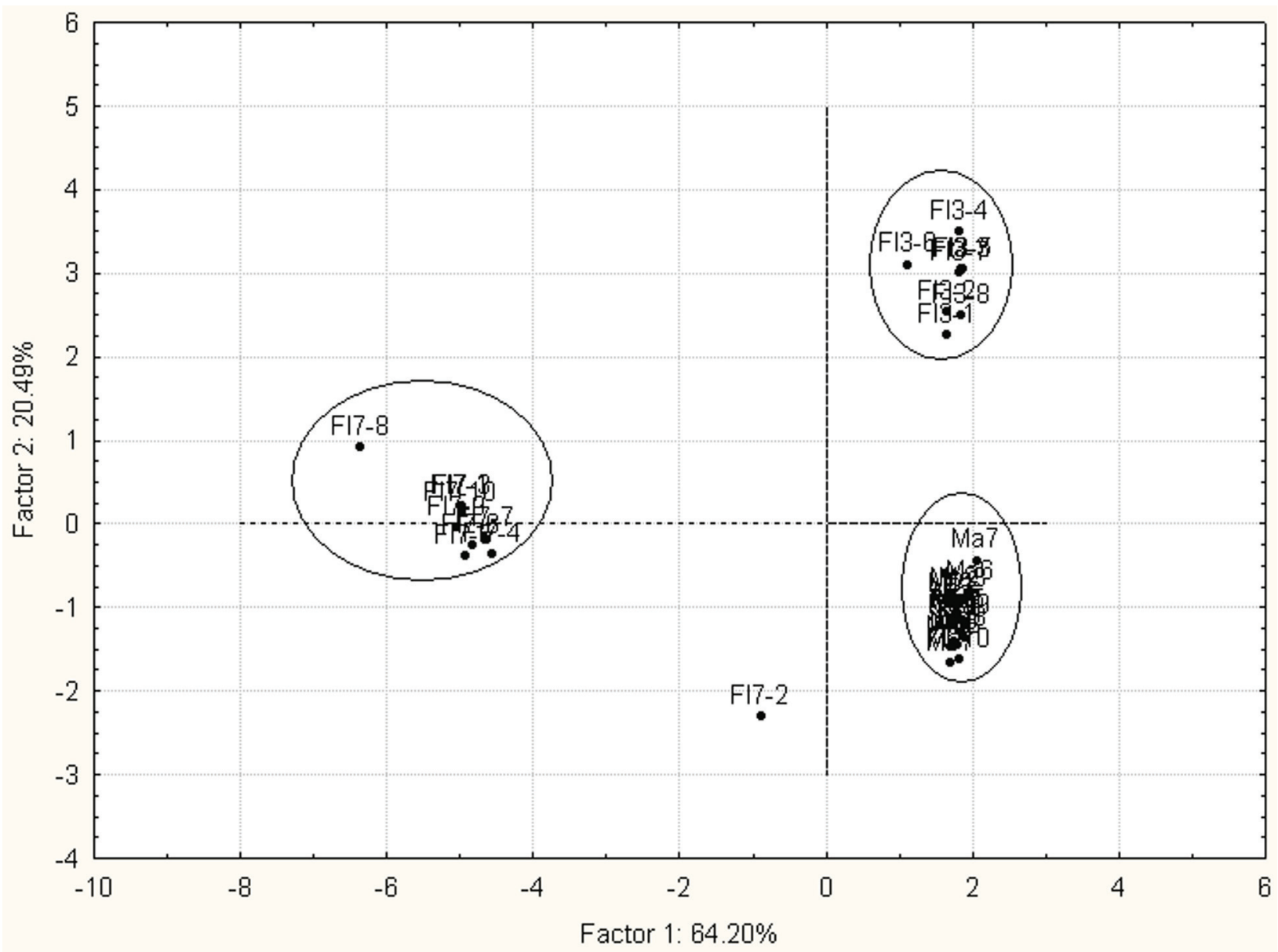

Figure 3. Factor scores in the first two calculated principal components for samples from the brand Ma (batches 154A and 154B, clustered in the lower right ellipse) and FI (batches 3 clustered at upper right ellipse and 7, clustered at middle left ellipse).

The clustering of the samples reveals that the Ma samples are quite uniform in their composition and pyrolysis pattern, resulting in all samples from both batches $154 \mathrm{~A}$ and 154B forming a single cluster. This is in marked contrast with the FI samples, which clustered as two separate groups corresponding to batches 3 and 7, suggesting a greater batch-to-batch variability of the samples. One sample of brand FI (batch 7, sample F17-2) did not clustered with the remaining samples of the same batch, suggesting sample inhomogeneity. These conclusions are also supported by the results of cluster analysis. The dendrogram in Figure 4 was obtained by the clustering of the different samples according to the calculated Euclidian distances between them, and the variability is represented in the abscissa, increasing from left to right. The dendrogram shown in Figure 4 confirms the trend outlined above, with samples from the Ma brand clustering together irrespective of batch, with a linkage distance of approximately 12 for samples (although most samples of Ma actually joined at a linkage distance of $c a$. 9). 


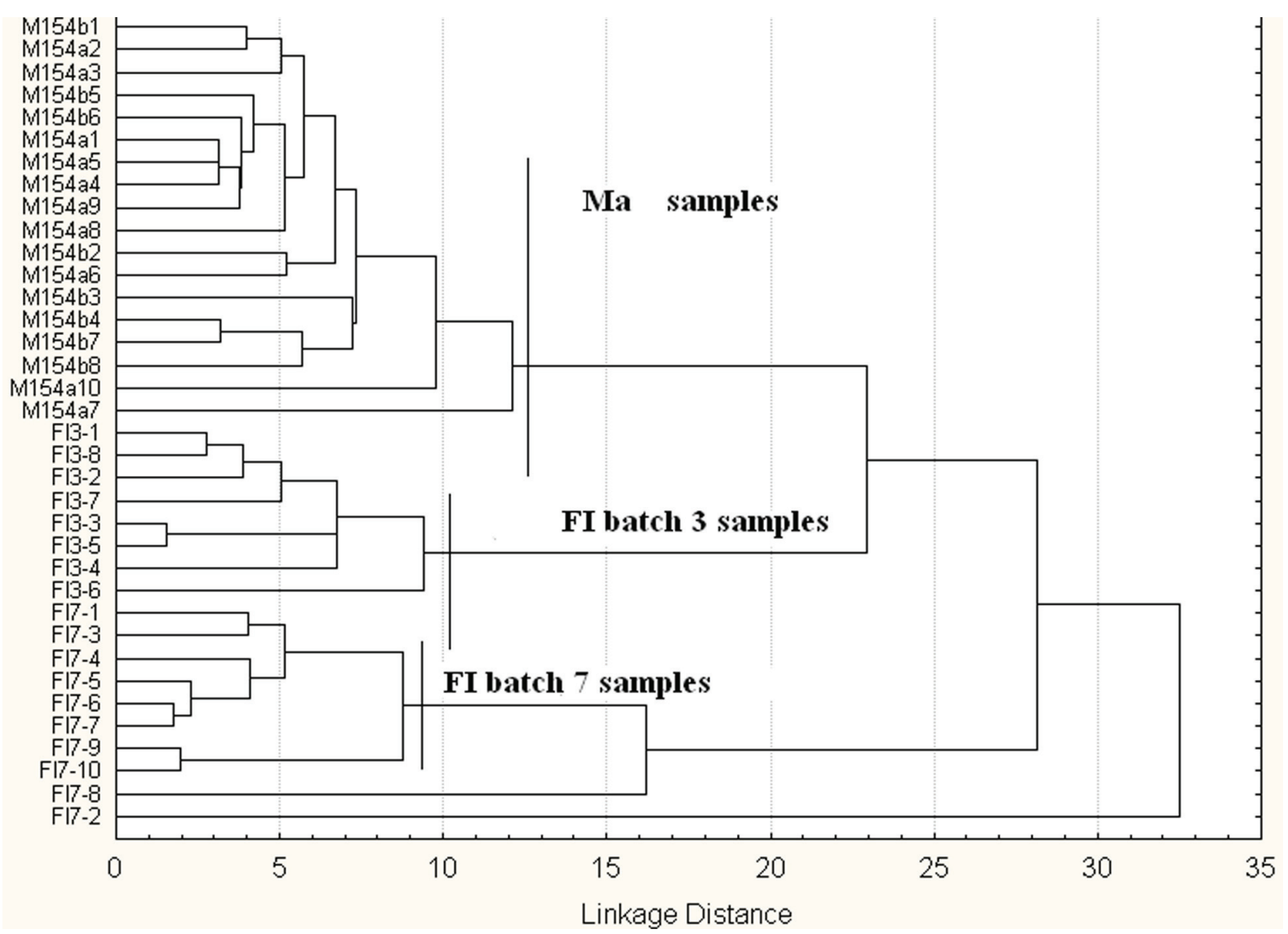

Figure 4. Dendrogram obtained from hierarchical cluster analysis of pyrolysis data from the hexane extract of commercial samples of C. citratus from the brands Ma and FI.

On the other hand, FI samples formed two different clusters (both with a linkage distance of $c a$. 9). The dendrogram also confirms the same behaviour of sample F17-2, which joined only with a linkage distance of ca. 32 .

\section{DISCUSSION}

Pyrolysis coupled to gas chromatography/mass spectrometry (Py-GC/MS) is rarely used for quantification purposes, but is often used as a fingerprinting technique for polymeric, biological and other complex samples due to the resulting complex pyrolysis pattern for those samples. The range of applicability of the technique is illustrated by its use in the forensic field for the differentiation of paints (Kochanowski \& Morgan, 2000; Zieba-Palus et al., 2008), analysis of whole organism in bacterial identification and classification (Barshick et al., 1999; Prasad et al., 2008) and analysis of vegetable material (Ibarra et al., 2007; Kim et al., 2003). The use of this technique in the analysis of herbal products has been very limited (Fang et al., 1990), but its potential is very promising. In a study by Yokoi et al. (Yokoi et al., 2001), the authors were able to discriminate samples of Eucaliptus camaldulensis grown from seeds of different origin based on the pyrolysis data using a microfurnace pyrolyser at $450{ }^{\circ} \mathrm{C}$. The authors identified syringyl and guaiacyl units derived from the lignan in the samples. This is illustrative of the power of the technique that can potentially be applied to identify small variations in the composition of a sample, such as those originating from different origin, batch-to-batch variability, and different brands. One of the main limitations of the technique includes the need for thermal degradation of the sample, which makes it difficult to relate the pyrogram to the original composition of the sample and results in the need for frequent cleaning of the liner and pyrolyser. However, multivariate analysis of data eliminates the need for peak identification, since it can use raw data, such as peak area and mass spectral data when available. Our results show that it is possible to use pyrolysis data to investigate the reproducibility of different brands and batches of Cymbopogon citratus. The method was able to reveal differences between different brands and even separate batches of the same brand. While qualitative in nature, we believe the technique can be potentially applied with success to the in-process control of the production of vegetable material and extracts for herbal medicines. 


\section{ACKNOWLEDGEMENTS}

The authors would like to thank Dr. Maria de Fátima Agra for the identification of the plant material. This work was supported by FAPESQ-PB and CNPq.

\section{REFERENCES}

Anvisa 2004. Resolução-RDC Nº. 48, de 16 de março de 2004. Dispõe sobre o registro de medicamentos fitoterápicos.

Barshick SA, Wolf DA, Vass AA 1999. Differentiation of microorganisms based on pyrolysis-ion trap mass spectrometry using chemical ionization. Anal Chem 71: 633-41.

Calixto JB 2000. Efficacy, safety, quality control, marketing and regulatory guidelines for herbal medicines (phytotherapeutic agents). Braz J Med Biol Res 33: 179189.

Christy AA, Bruchet A, Rybacki D 1999. Characterization of natural organic matter by pyrolysis/GC-MS. Environ Int 25: 181-189.

Diniz MFFM, Oliveira RAG, Medeiros ACD, Malta Júnior A (1997). Memento Fitoterápico. João Pessoa: Editora universitária UFPB.

Fang XC, Yu BY, Xiang BR, An DK 1990. Application of pyrolysis-high-resolution gas chromatography-pattern recognition to the identification of the Chinese traditional medicine mai dong. J Chromatogr 514: 287-92.

Ibarra D, Chavez MI, Rencoret J, Del Rio JC, Gutierrez A, Romero J, Camarero S, Martinez MJ, Jimenez-Barbero J, Martinez AT 2007. Lignin modification during Eucalyptus globulus kraft pulping followed by totally chlorine-free bleaching: a two-dimensional nuclear magnetic resonance, Fourier transform infrared, and pyrolysis-gas chromatography/mass spectrometry study. J Agric Food Chem 55: 3477-90.

Kim SW, Ban SH, Chung HJ, Choi DW, Choi PS, Yoo OJ, Liu JR 2003. Taxonomic discrimination of higher plants by pyrolysis mass spectrometry. Plant Cell Rep 22: 519522.

Kochanowski BK, Morgan SL 2000. Forensic discrimination of automotive paint samples using pyrolysis-gas chromatography-mass spectrometry with multivariate statistics. J Chrom Sci 38: 100-8.

Lavine BK 1998. Chemometrics. Anal Chem 70: 209R-228R.

Mitsui T, Hida M, Fujimura Y 1995. Determination of the Total Amount of Morphine Alkaloids in Opium By PyrolysisGas Chromatography Using Principal Component Analysis. J Anal Appl Pyrolysis 32: 205-212.

Petrovick PR, Marques LC, De Paula IC 1999. New rules for phytopharmaceutical drug registration in Brazil. $J$ Ethnopharmacol 66: 51-55.

Prasad S, Pierce KM, Schmidt H, Rao JV, Guth R, Synovec RE, Smith GB, Eiceman GA 2008. Constituents with independence from growth temperature for bacteria using pyrolysis-gas chromatography/differential mobility spectrometry with analysis of variance and principal component analysis. Analyst 133: 760-7.

Wampler TP 1999. Introduction to pyrolysis-capilary gas chromatography. J Chromatogr A 842: 207-220.

Wampler TP, Levy EJ 1987. Reproducibility in Pyrolysis - Recent Developments. J Anal Appl Pyrolysis 12: 75-82.
Wang LL, Ando S, Ishida Y, Ohtani H, Tsuge S, Nakayama T 2001. Quantitative and discriminative analysis of carnauba waxes by reactive pyrolysis-GC in the presence of organic alkali using a vertical microfurnace pyrolyzer. J Anal Appl Pyrolysis 58: 525-537.

White RL 1991. Microfurnace Pyrolysis Injector for Capillary Gas- Chromatography. J Anal Appl Pyrolysis 18: 269276.

Yokoi H, Nakase T, Ishida Y, Ohtani H, Tsuge S, Sonoda T, Ona T 2001. Discriminative analysis of Eucalyptus camaldulensis grown from seeds of various origins based on lignin components measured by pyrolysis-gas chromatography. J Anal Appl Pyrolysis 57: 145-152.

Zieba-Palus J, Zadora G, Milczarek JM 2008. Differentiation and evaluation of evidence value of styrene acrylic urethane topcoat car paints analysed by pyrolysis-gas chromatography. J Chromatogr A 1179: 47-58. 